\title{
Diversity and ethnobotanical study of medicinal plants in Ban Hua Kua, Kae Dam District, Thailand
}

\author{
WILAIJIT NUMPULSUKSANT ${ }^{1}$, SURAPON SAENSOUK ${ }^{1}$, PIYAPORN SAENSOUK $^{2, v}$ \\ ${ }^{1}$ Plant and Invertebrate Taxonomy and Its Applications Unit Group, Biodiversity program, Walai Rukhavej Botanical Research Institute, \\ Mahasarakham University. Kantarawichai District, Maha Sarakham, 44150, Thailand \\ ${ }^{2}$ Plant and Invertebrate Taxonomy and Its Applications Unit Group, Department of Biology, Faculty of Science, Mahasarakham University. \\ Kantarawichai District, Maha Sarakham, 44150, Thailand. `email: pcornukaempferia@yahoo.com
}

Manuscript received: 14 August 2021. Revision accepted: 23 September 2021

\begin{abstract}
Numpulsuksant W, Saensouk S, Sanesouk P. 2021. Diversity and ethnobotanical study of medicinal plants in Ban Hua Kua, Kae Dam District, Thailand. Biodiversitas 22: 4349-4357. Diversity and ethnobotanical study of medicinal plants in Ban Hua Kua village, Kae Dam District, Maha Sarakham Province, Thailand. Biodiversitas 22: xxxx-xxxx. This study can serve as basic information for further study and provide conservation criteria for medicinal plants in Ban Hua Kua village, Kae Dam District, Maha Sarakham Province to assure continued species richness and sustainable use. This study aimed to document ethnobotanical knowledge of medicinal plants, including their diversity, in Ban Hua Kua village, Kae Dam District, Maha Sarakham Province, Thailand. The ethnobotanical data were obtained from 19 local experts using semi-structured forms to record the interviewee's personal information and topics related to the medicinal use of specific plants. Thirty-eight medicinal plants belonging to 35 genera in 23 families were collected. The most commonly represented family was Zingiberaceae comprised of six species (Alpinia galanga (L.) Willd., Boesenbergia rotunda (L.) Mansf., Curcuma angustifolia Roxb., Curcuma comosa Roxb., Curcuma longa L., and Zingiber officinale Roscoe), followed by Fabaceae with four species (Derris scandens (Roxb.) Benth., Dialium cochinchinense Pierre, Senna siamea Lam., and Tamarindus indica L.), and Rutaceae with three species (Aegle marmelos (L.) Corrêa ex Roxb., Clausena wallichii Oliv., Hesperethusa crenulata (Roxb.) Roem.), while the other 20families represent only one to two plant species. The root was the most frequently used part of the plant. The species with the highest use-value was Antiaris toxicaria Lesch. (0.68), a native plant of the Ban Hua Kuavillage. Diospyros mollis Griff. $(\mathrm{CI}=0.21)$, Dialium cochinchinense Pierre $(\mathrm{CI}=0.21)$, Anisomeles indica $(\mathrm{L}.) \mathrm{Kuntze}(\mathrm{CI}=$ $0.21)$, Vitex glabrata $\mathrm{R} . \mathrm{Br} .(\mathrm{CI}=0.21)$, Aegle marmelos $(\mathrm{L}$.$) Corrêa ex Roxb. (\mathrm{CI}=0.21)$, Phyllanthus emblica $\mathrm{L} .(\mathrm{CI}=0.21)$, and Hesperethusa crenulata (Roxb.) Roem. $(\mathrm{CI}=0.21)$ were found the highest cultural important index $(\mathrm{CI})$, while Diospyros mollis Griff., Dialium cochinchinense Pierre, Anisomeles indica (L.) Kuntze, Vitex glabrata R. Br., Phyllanthus emblica L., Aegle marmelos (L.) Corrêa ex Roxb., and Hesperethusa crenulata (Roxb.) Roem. were found the highest $\% \mathrm{FL}=50$. The climber was mostly used for medicinal plants $($ IAR $=0.97)$. Root $(57.89 \%$ (, leaf $(52.63 \%($, and fruit $(39.47 \%$ ( were reported the most plant parts used by the villagers. Therefore, the indigenous knowledge of medicinal plants at Ban Hua Kua village is indicated to conservation for sustainable use in the future. Moreover, this study was the first reported in Maha Sarakham province.
\end{abstract}

Keywords: Diversity, ethnobotany, medicinal plants, Kae Dam District, Maha Sarakham, Thailand

\section{INTRODUCTION}

The Thai people in northeastern Thailand, which also called "Isan people" have many unique traditional plants and cultural customs. Isan life depends on natural plant resources of neighboring forests for food, medicine, building a house, and make home appliances.

Ethnobotany is the study of local traditional knowledge of utilizing indigenous plants for food, medicine, appliances, and others, which have been practicing and usesfor a long time, passed on from generation to generation. The utilization of each plant species is also varied in each region especially applied in nature to the advantage of ethnic groups (Anderson 1993, Santasombat 2001). Moreover, ethnobotanical studies have also shown a great variation in the traditional utilization of medicinal plants among different cultural and social groups (Anderson 1993, Lee et al. 2008).

The study of medicinal plants is one of the methods to determine the relationships between cultural components of the environment and biological including examining the interaction (Bye 1986). There are various studies on ethnobotany and medicinal plants in Maha Sarakham Province and other places in Thailand such as Srithi (2009) reported the knowledge of medicinal plant and its erosion among the Mien (Yao) in northern, Saensouk et al. (2016) studied diversity and uses of Zingiberaceae in Nam Nao National Park, Pholhiamhan et al. (2018) reported the ethnobotany of Phu Thai Ethnic group in Nakhon Phanom Province, Junsongduang et al. (2020) recognized ethnomedicinal knowledge of traditional healers in Roi Et Province, and Saensouk and Saensouk (2021) studied diversity, traditional uses, and conservation status of Zingiberaceae in Udon Thani Province.

Moreover, several studies reported from other regions in the world such as Huai and Pei (2004) studied medicinal plants in the Lahu people from the Autonomous County of Jinping Miao, Yao, and Dai in southwest China, Gazzaneo et al. (2005) studied in a region of Atlantic Forest in the state of Pernambuco (Northeastern Brazil), Chaudhary et al. 
(2006) reported from Tian Mu Shan Biosphere Reserve, Zhejiang Province, China, Yineger et al. (2008) studied in the Oromo ethnic group in southwestern Ethiopia, Supiadi et al. (2019) studied the Dayak Desa Community in Sintang, West Kalimantan, Indonesia, and Susandarina et al. (2021) studied in the Malays communities in Kampar Kiri Hulu, Riau, Indonesia.

Ban Hua Kua village is located at Kae Dam District, Maha Sarakham Province. The village area has an important forest for the daily life of local people that is "Nong Kra Nuan forest", which is a large dry dipterocarp forest utilized by 175 households living in the surrounding forest as a source for a living, such as food, medicine, other uses, and it is a bond to relationships among people in the community. The local people in the community jointly maintain and utilize plants in the Nong Kra Nuan forest based on their local wisdom, resulted from experiencing and adapting to the physical, social, and cultural environments. At present, the ethnobotanical study is becoming increasingly important in formulating strategies and actions for preserving or restoring remaining forests. This study records the diversity and uses of medicinal plants in Ban Hua Kua village, including analysis of medicinal plants using qualitative and quantitative ethnobotany. This study is the first report conducted in this area and presents the relationship between the tastes of medicinal plants and the selection of plants for effective medication that has never been studied before. While the younger generation is less interested in using medicinal plants than in the past due to the development of science and technology, we are hoping this study would be useful data for future generations as a guideline for plant conservation. Therefore, this study aims to document ethnobotanical knowledge of medicinal plants, including their diversity, in Ban Hua Kua village, Kae Dam District, Maha Sarakham Province, Thailand.

\section{MATERIALS AND METHODS}

\section{Study area and data collection}

An ethnobotanical study on the utilization of medicinal plants was collected for one year in 2018 with the help of rural dwellers of the Ban Hua Kua $\left(16^{\circ} 00^{\prime} 22.2^{\prime \prime} \mathrm{N}\right.$ 103⒉11.5"E), Maha Sarakham province, Thailand (Figure 1). Data were obtained using semi-structured forms to record the personal information of the interviewee and topics related to the medicinal use of specific plants (Pholhiamhan et al. 2018). During the first contact with the local population, a specialist was identified by the inhabitants themselves. Nineteen local specialists were eventually interviewed (12 men and seven women), aged 20-63. All community experts interviewed were those who were exposed to the experience, the exchange of knowledge among generations in the same family, and among people in the community, the knowledge of the use and properties have been passed on to the present. But there is a high risk that in the future, this traditional knowledge about medicinal plants will be lost due to the development of science and technology. The area of the study is the part of the Korat plateau, a broad, shallow basin that lies at an elevation of 100-200 meters above sea level, between latitude $14-19^{\circ} \mathrm{N}$ and longitude $101-106^{\circ} \mathrm{E}$. The floodplains of the Mun and Chi rivers cover most of the region. Korat Plateau is separated from the central region of Thailand by the Phetchabun mountain range and San Kamphaeng mountains. There is the Dong PhayaYen mountain range in the southwestern and the Phanom Dong Rak mountain range in the south that also separates Cambodia from Thailand (Pholhiamhan et al. 2018).

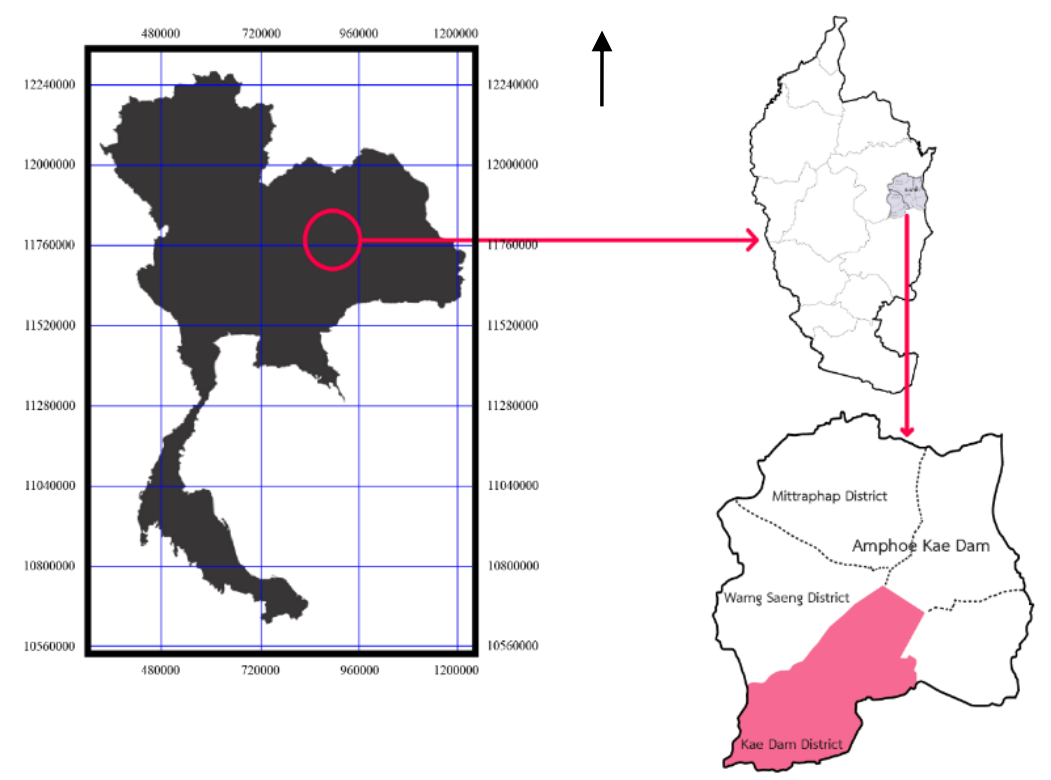

Figure 1. The location of Ban Hua Kua, Kae Dam District, Maha Sarakham Province, Thailand 
The dried specimens of medicinal plants were collected to be voucher specimens and deposited at Mahasarakham University Herbarium, Maha Sarakham Province, Thailand. The scientific names were identified according to the identification key to species and existing taxonomic literature, such as Phengklai 1972; Nanakorn 1985; Sirirugsa 1992; Pooma 1999, 2002; Theilade 1999; Saensouk et al. 2003, 2021a, 2021b, 2021c; Middleton 2009; Bunwong et al. 2014; Triboun et al. 2014; Duangjai 2018; Bunchalee et al. 2021. The scientific names were verified using an online database, Plants of the World Online or POWO (KewScience 2021).

\section{Data analysis}

Data were analyzed using indigenous botanical indices used for calculating the data obtained from having interviews with data providers (Inta 2008(.

\section{Use Value}

The Use Value index or UV is an index originally developed by Prance et al. (1987), independent of informant consensus, and in contrast, based only on the diversity of plant uses. Regardless of informant variation, this index was initially defined as a sum of uses for a given plant species, using a value of 1.0 for "the major" uses, 0.5 for "the minor" uses, and 0 for "no use". Afterward, for a more objective index, Phillips and Gentry (1993) modified the index of Prance et al. (1987) by taking the number of informants mentioning uses of a given plant into account.

$$
\mathrm{UV}=\frac{\mathbf{\Sigma} U i}{N}
$$

The Use Value index is calculated by the formula, which $U i$ is the number of use reports cited by each informant for a given species, and $N$ refers to the total number of informants. Use values are high when there are many utilization reports for a plant, implying that the plant is important, and approach zero (0) when there are few reports related to its use. Thus, plants mentioned with more frequency were assigned more use value than plants mentioned with less frequency (Reyes-García et al. 2006). However, the Use Values do not distinguish whether a plant is used for single or multiple purposes; for example, a rarely used plant with two cited uses would be more important than a very popular plant with only one use (Kvist et al. 1995). Photographs of plants were taken, and the morphology of each plant was characterized (Martin 1995; Thomas et al. 2007; Cook 1995).

\section{Cultural Importance Index}

The Cultural Importance Index (CI) is a quantitative index that presents the importance of a particular plant in the locality by dividing its use into groups with different parts of the plant, so it is acknowledged which part of the plant is important for the benefits (Tardio and PardodeSantayana 2008(. It is calculated by using the following formula:

$$
\mathrm{CI}=\sum_{U=1}^{N C} \sum_{i=1}^{N} \frac{U R u i}{N}
$$

Where: URui is the quantity of different parts of plants used for utilization based on each contributor, and $N$ means the total number of providers. $N C$ is the total quantity of plants used. The CI will have the highest value equal to the total quantity of plants used for benefit. It means that all informants have used the whole plant for utilization.

\section{Informant Agreement Ratio}

Informant Agreement Ratio (IAR) is an index used to measure acceptance between data providers and plant utilization (Trotter and Logan, 1986; Heinrich et al. 1998(. This consistency shows a high level of acceptance, and it is a good way to utilize such plants (Heinrich et al. 1998) by calculating IAR with the following formula:

$$
\mathrm{IAR}=\frac{N u r-N t}{N u r-1}
$$

Where: Nur is the quantity of plants that have been obtained from all data providers. $N t$ is the quantity of plants used for utilization. IAR values are in the range of 1 to 0 . If the IAR values are close to or equal to 1 , it shows that the plant has been recognized by many people.

\section{Fidelity Level}

Fidelity Level (\% FL) is an index used to analyze which plants are the most interesting in each utilization group by the formula as follows:

$$
\% \mathrm{FL}=\frac{N p}{N} \times 100
$$

Where: $N p$ is the quantity of plants that are utilized. $N$ is the quantity of parts of all plants that are utilized. The higher the \% FL means the higher the parts of the plants are used for utilization. The highest value equals $100 \%$, whereas the low \% FL means various parts of plants are used for utilization (Friedmann et al. 1986).

\section{RESULTS AND DISCUSSIONS}

The ethnobotanical study on the utilization of medicinal plants in Ban Hua Kua village, Kae Dam District, Maha Sarakham Province, Thailand, recorded 38 species of medicinal plants belonging to 35 genera in 23 families, and the Zingiberaceae was the most representative family obtained on the surveyed site. The data as shown in Table 1 included the family name, botanical name, vernacular name, and plant part used, along with its voucher specimen number and the result of the data analysis are present below:

\section{Diversity of medicinal plants}

The most representative family was Zingiberaceae comprised of six species, i.e. Alpinia galanga, Boesenbergia rotunda, Curcuma angustifolia, C. comosa, C. longa, and Zingiber officinale followed by Fabaceae 
with four species (Derris scandens, Dialium cochinchinense, Senna siamea, and Tamarindus indica), and Rutaceae with three species (Aegle marmelos, Clausena wallichii, and Hesperethusa crenulata), while six families namely Ebernaceae, Hypericaceae, Lamiaceae, Moraceae, Phyllanthaceae, and Rubiaceae represent two species. Whereas 14 families, including Annonaceae, Apocynaceae, Asteraceae, Burseraceae, Celastraceae, Combretaceae, Cucurbitaceae, Cyperaceae, Malvaceae, Menispermaceae, Periplocaceae, Poaceae, Rosaceae, and Simaroubaceae were represented only one species (Table 1). The result was used the medicinal plants from table 1 , i.e. Aganonerion polymorphum, Alpinia galanga, Aegle marmelos, Bambusa bambos, Boesenbergia rotunda, Curcuma longa, Diospyros mollis, Phyllanthus emblica, Senna siamea, Tamarindus indica, Zingiber officinale, which is in agreement with the study of Pholhiamhan et al. (2018) and Saensouk and Saensouk (2021).

\section{Use Value}

Antiaris toxicaria with its highest Use Value (0.68) which indicates that the species has great importance for daily life to the local people in Kae Dam District, followed by Streptocaulon juventas $) \mathrm{UV}=0.47$ (, Elephantopus scaber $) \mathrm{UV}=0.32($, Neoachmandra indica $) \mathrm{UV}=0.32($, Anisomeles indica )UV $=0.32$ (, and Clausena wallichii ) $\mathrm{UV}=0.32$ (. In compartison, six species, namely Tamarindus indica, Streblus asper, Tinospora crispa, Hymenocardia punctata, Alpinia galanga, and Boesenbergia rotunda have the lowest Use Value (0.05) )Figure 2(.

\section{Cultural Importance Index}

Seven species have the highest cultural important index (CI), i.e. Diospyros mollis $) \mathrm{CI}=0.21($, Dialium cochinchinense $) \mathrm{CI}=0.21$, Anisomeles indica $) \mathrm{CI}=0.21$, Vitex glabrata $) \mathrm{CI}=0.21($, Aegle marmelos $(\mathrm{CI}=0.21)$, Phyllanthus emblica $) \mathrm{CI}=0.21($, and Hesperethusa crenulata $) \mathrm{CI}=0.21$ ( which various parts were used, while eight species namely Polyalthia evecta, Derris scandens, Tinospora crispa, Bambusa bambos, Rothmannia wittii, Clausena wallichii, Eurycoma longifolia, and Curcuma comosa have the lowest Cultural Important Index $(\mathrm{CI}=$ 0.05), a high CI value indicates that many parts of the plant are used whereas a numeric value approaching zero means that only one or two part of the plant is used )Figure 3(.

\section{Fidelity Level}

Fidelity Level (\%FL) of medicinal plants in Ban Hua Kua showed that seven species namely Diospyros mollis, Dialium cochinchinense, Anisomeles indica, Vitex glabrata, Phyllanthus emblica, Aegle marmelos, and Hesperethusa crenulata have the highest Fidelity Level $(\% \mathrm{FL}=50)$ which means the parts of the plants are used more than other species, followed by eight species with $\% \mathrm{FL}=37.5$ included Elephantopus scaber, Neoachmandra indica, Diospyros filipendula, Cratoxylum formosum, Streblus asper, Microcos tomentosa, Hymenocardia punctata, Zingiber officinale, and 14 species with $\% \mathrm{FL}=$ 25.0 included Aganonerion polymorphum, Canarium sabulatum, Salacia chinensis, Terminalia chebula, Cyperus rotundus, Senna siamea, Antiaris toxicaria, Streptocaulon juventas, Prunus cerasoides, Paederia linearis, Alpinia galanga, Boesenbergia rotunda, Curcuma angustifolia, $C$. longa, and eight species with $\% \mathrm{FL}=12.5$ included Polyalthia evecta, Derris scandens, Tinospora crispa, Bambusa bambos, Rothmannia wittii, Clausena wallichii, Eurycoma longifolia, C. comosa, while Tamarindus indica has the lowest Fidelity Level $(\% \mathrm{FL}=2.0)$ indicated that this species is not much popular inusing as medicinal plants among other species in Ban Hua Kua.

\section{Informant Agreement Ratio}

Informant Agreement Ratio (IAR) of medicinal plants in Ban Hua Kua found that Climber )0.97( was the part of the plant that is mostly used for utilization, followed by rhizome $(0.86$ (, and fruit $(0.86$ ( as the second-ranked, while the lowest in the rank was root $(0.43)$ (Figure 4(. The high number of IAR indicates that the species has been recognized by many people, in other words, most villagers in the study area use climber and rhizomes as a medicinal purpose in their daily life.

\section{Parts of the plant used}

Root $57.89 \%$ ( was the most useful part, although it has not been recognized by most villagers, followed by leaf (52.63\%), and fruit (39.47\%(. They are the important parts of plants for utilization towards local people as in the result of other studies, which found that root and leaf are mostly used Huaiand Pei (2004), Gazzaneo et al. (2005), Chaudhary et al. (2006); Yineger et al. (2008), Srithi (2009).

From the survey in this study, it was found that most of the utilized medicinal plants were collected directly from the wild without being propagated. Only some of them were planted in villagers' homes to provide convenience when needed immediately without having to go into the woods, which requires travel and time. This indirectly contributes to conservation by reducing the removal of plants from the forest. However, community experts on medicinal plants agree that many medicinal plants are increasingly rare and endangered in natural forests because many of those plants are taken out of the forest without cultivation or conservation.

In conclusion, the study has enabled us to document the traditional knowledge in theuse of medicinal plants in Ban Hua Kua, Kae Dam District, Maha Sarakham Province. The most representative species is belonging to the Zingiberaceae family comprised of six species (Alpinia galanga, Boesenbergia rotunda, Curcuma angustifolia, $C$. comosa, C. longa, and Zingiber officinale), followed by Fabaceae with fourspecies (Derris scandens, Dialium cochinchinense, Senna siamea, and Tamarindus indica), and Rutaceae with three species (Aegle marmelos, Clausena wallichii, Hesperethusa crenulata), while the other 20 families represent only one to two species. Antiaris toxicaria has great importance to the locals, followed by Streptocaulon juventas, Elephantopus scaber, Neoachmandra indica, Anisomeles indica, and Clausena wallichii. 
Table 1. List of medicinal plants used in Ban Hua Kua, Kae Dam District, Maha Sarakham Province, Thailand

\begin{tabular}{|c|c|c|c|c|c|c|c|c|}
\hline Family & Scientific name & $\begin{array}{l}\text { Vernacular name } \\
\text { (Isan name) }\end{array}$ & Parts used & Medicinal uses & $\mathbf{U V}$ & $\% \mathrm{FL}$ & CI & Collector No. \\
\hline Annonaceae & $\begin{array}{l}\text { Polyalthia evecta (Pierre) } \\
\text { Finet \& Gagnep. }\end{array}$ & Bak tong leeng & Root & Boiling root & 0.16 & 12.5 & 0.05 & Numpulsuksant 033 \\
\hline Apocynaceae & $\begin{array}{l}\text { Aganonerion polymorphum } \\
\text { Pierre ex Spire }\end{array}$ & Somlom & Root, leaf & Boiling root, leaf & 0.21 & 25.0 & 0.11 & Numpulsuksant 071 \\
\hline Asteraceae & Elephantopus scaber L. & Do mairulom & Root, leaf, stem & Boiling root, leaf, stem & 0.32 & 37.5 & 0.16 & Numpulsuksant 031 \\
\hline Burseraceae & Canarium sabulatum Guillaumin & Bakkokluwam & Fruit, bark & $\begin{array}{l}\text { Boiling bark, } \\
\text { Pounded or eaten fresh as fruit }\end{array}$ & 0.26 & 25.0 & 0.11 & Numpulsuksant 057 \\
\hline Celastraceae & Salacia chinensis L. & Kam phaengjedchan & Root, stem & Boil fresh roots and stems to mask skin lesions & 0.26 & 25.0 & 0.11 & Numpulsuksant 008 \\
\hline Combretaceae & Terminalia chebula Retz. & Sommor & Fruit, bark & $\begin{array}{l}\text { Boiling bark, } \\
\text { Eaten fresh as fruit }\end{array}$ & 0.26 & 25.0 & 0.11 & Numpulsuksant 072 \\
\hline Cucurbitaceae & $\begin{array}{l}\text { Neoachmandra indica } \\
\text { (Lour.) W. J. de Wilde \& Duyfjes }\end{array}$ & Tum lung & Root, leaf, fruit & $\begin{array}{l}\text { Young leaves are used for cooking soup or curry, } \\
\text { Fresh fruit and fresh roots, masked or applied to the } \\
\text { skin }\end{array}$ & 0.32 & 37.5 & 0.16 & Numpulsuksant 037 \\
\hline Cyperaceae & Cyperus rotundus $\mathrm{L}$. & Yahaew moo & Root, leaf & $\begin{array}{l}\text { Boil the roots and leaves for a poultice for treating } \\
\text { abscesses }\end{array}$ & 0.26 & 25.0 & 0.11 & Numpulsuksant 078 \\
\hline \multirow[t]{2}{*}{ Ebenacaae } & $\begin{array}{l}\text { Diospyros filipendula } \\
\text { Pierre ex Lecomte }\end{array}$ & Khan jong & Root, leaf, fruit & $\begin{array}{l}\text { Boil roots and leaves and mix with bath water, Eaten } \\
\text { fresh as fruit }\end{array}$ & 0.26 & 37.5 & 0.16 & Numpulsuksant 018 \\
\hline & Diospyros mollis Griff. & Maakgleua & $\begin{array}{l}\text { Root, leaf, fruit, } \\
\text { bark }\end{array}$ & $\begin{array}{l}\text { Eaten fresh as fruit, } \\
\text { Boil roots, bark and leaves and mix with bath }\end{array}$ & 0.26 & 50.0 & 0.21 & Numpulsuksant 058 \\
\hline \multirow[t]{4}{*}{ Fabaceae } & Derris scandens (Roxb.) Benth. & Khrueataapla & Root & Boil roots as a local herble tea & 0.26 & 12.5 & 0.05 & Numpulsuksant 021 \\
\hline & Dialium cochinchinense Pierre & Bakkheng & $\begin{array}{l}\text { Root, leaf, fruit, } \\
\text { bark }\end{array}$ & $\begin{array}{l}\text { Boil roots, bark and young leaves and mix with bath, } \\
\text { Eaten fresh as fruit }\end{array}$ & 0.26 & 50.0 & 0.21 & Numpulsuksant 019 \\
\hline & Senna siamea Lam. & $\begin{array}{l}\text { Phakkheelek, } \\
\text { Kheelek }\end{array}$ & Leaf, flower & $\begin{array}{l}\text { Young leaves and young flowers are used for cooking } \\
\text { local soup }\end{array}$ & 0.26 & 25.0 & 0.11 & Numpulsuksant 014 \\
\hline & Tamarindus indica $\mathrm{L}$. & $\begin{array}{l}\text { Bakkaam, } \\
\text { Maakkaam }\end{array}$ & Leaf, fruit & $\begin{array}{l}\text { Eaten fresh as fruit, Young leaves and fruits are used } \\
\text { for cooking local soup }\end{array}$ & 0.05 & 2.0 & 0.11 & Numpulsuksant 060 \\
\hline Hypericaceae & $\begin{array}{l}\text { Cratoxylum formosum } \\
\text { (Jacq.) Benth. \& Hook. f. ex Dyer }\end{array}$ & Tewkao & $\begin{array}{l}\text { Root, leaf, } \\
\text { flower }\end{array}$ & $\begin{array}{l}\text { Young leaves eaten as fresh vegetable, } \\
\text { Young leaves and flowers are used for cooking local } \\
\text { soup, } \\
\text { Fresh roots soaked in water and drink, } \\
\text { Pound the leaves for mask the skin }\end{array}$ & 0.26 & 37.5 & 0.16 & Numpulsuksant 038 \\
\hline \multirow[t]{2}{*}{ Lamiaceae } & Anisomeles indica (L.) Kuntze & Saapsuea & $\begin{array}{l}\text { Root, leaf, fruit, } \\
\text { stem }\end{array}$ & Chewing hemostatic leaves & 0.32 & 50.0 & 0.21 & Numpulsuksant 076 \\
\hline & Vitex glabrata $\mathrm{R} . \mathrm{Br}$. & Khainao & $\begin{array}{l}\text { Root, fruit, bark, } \\
\text { stem }\end{array}$ & $\begin{array}{l}\text { Eaten fresh as fruit, } \\
\text { Boil roots, bark, stem as a local herble tea }\end{array}$ & 0.26 & 50.0 & 0.21 & Numpulsuksant 016 \\
\hline \multirow[t]{2}{*}{ Moraceae } & Antiaris toxicaria Lesch. & Yaanang & Root, leaf & Pound the fresh leaves with roots and squeeze the water & 0.68 & 25.0 & 0.11 & Numpulsuksant 067 \\
\hline & Streblus asper Lour. & $\mathrm{Kh}$ & Root, leaf, bark & Pound the leaf and bark and boil root and bark & 0.05 & 37.5 & 0.16 & Numpulsuksant 011 \\
\hline Malvaceae & Microcos tomentosa $\mathrm{Sm}$. & Komsom & Fruit, bark, stem & $\begin{array}{l}\text { Eaten fresh as fruit, } \\
\text { Boil bark and stem as a local herble tea }\end{array}$ & 0.16 & 37.5 & 0.16 & Numpulsuksant 017 \\
\hline
\end{tabular}




\begin{tabular}{|c|c|c|c|c|c|c|c|c|}
\hline Menispermaceae & $\begin{array}{l}\text { Tinospora crispa (L.) Hook. F. \& } \\
\text { Thomson }\end{array}$ & Khrueakaohor & Climber & $\begin{array}{l}\text { The stems are ground into powder and made into a } \\
\text { bolus. }\end{array}$ & 0.05 & 12.5 & 0.05 & Numpulsuksant 020 \\
\hline Periplocaceae & $\begin{array}{l}\text { Streptocaulon juventas (Lour.) } \\
\text { Merr. }\end{array}$ & Khruea tai song & Root, stem & $\begin{array}{l}\text { Boil root and stem as a local herble tea, } \\
\text { The roots are dried and ground into powder }\end{array}$ & 0.47 & 25.0 & 0.11 & Numpulsuksant 022 \\
\hline \multirow[t]{2}{*}{ Phyllanthaceae } & $\begin{array}{l}\text { Hymenocardia punctata Wall. ex } \\
\text { Lindl. }\end{array}$ & Hoo ling & $\begin{array}{l}\text { Root, leaf, stem, } \\
\text { fruit }\end{array}$ & $\begin{array}{l}\text { Eaten fresh as fruit, } \\
\text { Boil root, leaf and stem as a local herble tea }\end{array}$ & 0.05 & 37.5 & 0.16 & Numpulsuksant 084 \\
\hline & Phyllanthus emblica $\mathrm{L}$. & Bakkaampom & $\begin{array}{l}\text { Root, leaf, fruit, } \\
\text { bark }\end{array}$ & $\begin{array}{l}\text { Eaten fresh as fruit, } \\
\text { Pound the leaves for the treatment of skin diseases }\end{array}$ & 0.26 & 50.0 & 0.21 & Numpulsuksant 061 \\
\hline Poaceae & Bambusa bambos (L.) Voss & Nawmaiphaipaa & Young stem & Boil young stem as local food & 0.21 & 12.5 & 0.05 & Numpulsuksant052 \\
\hline Rosaceae & Prunus cerasoides D. Don & Phayasueakhrong & Fruit, bark & Boil bark and fruit as a local herble tea & 0.26 & 25.0 & 0.11 & Numpulsuksant 053 \\
\hline \multirow[t]{2}{*}{ Rubiaceae } & Paederia linearis Hook. f. & Tot moo tot maa & Leaf, climber & Boil leaf and climber as a local herble tea & 0.26 & 25.0 & 0.11 & Numpulsuksant 032 \\
\hline & Rothmannia wittii (Craib.) Bremek. & Bakmor, Maakmor & Fruit & Pickled fruit & 0.26 & 12.5 & 0.05 & Numpulsuksant 080 \\
\hline \multirow[t]{3}{*}{ Rutaceae } & $\begin{array}{l}\text { Aegle marmelos (L.) Corrêa ex } \\
\text { Roxb. }\end{array}$ & $\begin{array}{l}\text { Baktuum, } \\
\text { Maaktuum }\end{array}$ & $\begin{array}{l}\text { Root, leaf, fruit, } \\
\text { bark }\end{array}$ & Boil root, leaf, fruit and bark as a local herble tea & 0.26 & 50.0 & 0.21 & Numpulsuksant 062 \\
\hline & $\begin{array}{l}\text { Clausena wallichii var. guillauminii } \\
\text { (Tanaka) Molino }\end{array}$ & Song faa & Root & Crush the roots and apply water to cure the abscess & 0.32 & 12.5 & 0.05 & Numpulsuksant 073 \\
\hline & $\begin{array}{l}\text { Naringi crenulata (Roxb.) } \\
\text { Nicolson. }\end{array}$ & Krajae, tum tang & $\begin{array}{l}\text { Root, leaf, fruit, } \\
\text { stem }\end{array}$ & Boil root, leaf, fruit and stem as a local herble tea & 0.26 & 50.0 & 0.21 & Numpulsuksant 002 \\
\hline Simaroubaceae & Eurycoma longifolia Jack & Plalaipeuak & Root & Boil r & 0.26 & 12.5 & 0.05 & Nun \\
\hline \multirow[t]{6}{*}{ Zingiberaceae } & Alpinia galanga $(\mathrm{L}$.$) Willd.$ & Kaa & Rhizome, flower & Eaten fresh rhizome and flower as a herble vegetable & 0.05 & 25.0 & 0.11 & Numpulsuksant 012 \\
\hline & Boesenbergia rotunda (L.) Mansf. & Kra chai & Rhizome, leaf & Eaten rhizome and leaf as a herble vegetable & 0.05 & 25.0 & 0.11 & Numpulsuksant 003 \\
\hline & Curcuma angustifolia Roxb. & Krajeaw & Rhizome & Eaten fresh rhizome as a herble vegetable & 0.26 & 25.0 & 0.11 & Numpulsuksant 001 \\
\hline & Curcuma comosa Roxb. & Wan maawor & Rhizome & Grind the rhizomes to apply to wounds & 0.26 & 12.5 & 0.05 & Numpulsuksant 070 \\
\hline & Curcuma longa $\mathrm{L}$. & Kha min & Rhizome & $\begin{array}{l}\text { Eaten fresh rhizome as a herble vegetable, } \\
\text { The rhizomes are used for insect bites, } \\
\text { Ground into herbal powder }\end{array}$ & 0.26 & 25.0 & 0.11 & Numpulsuksant 010 \\
\hline & Zingiber officinale Roscoe & Khing & Rhizome, leaf & $\begin{array}{l}\text { Eaten fresh rhizome and leaf as a herble vegetable, } \\
\text { Ground into herbal powder }\end{array}$ & 0.11 & 37.5 & 0.16 & Numpulsuksant 013 \\
\hline
\end{tabular}




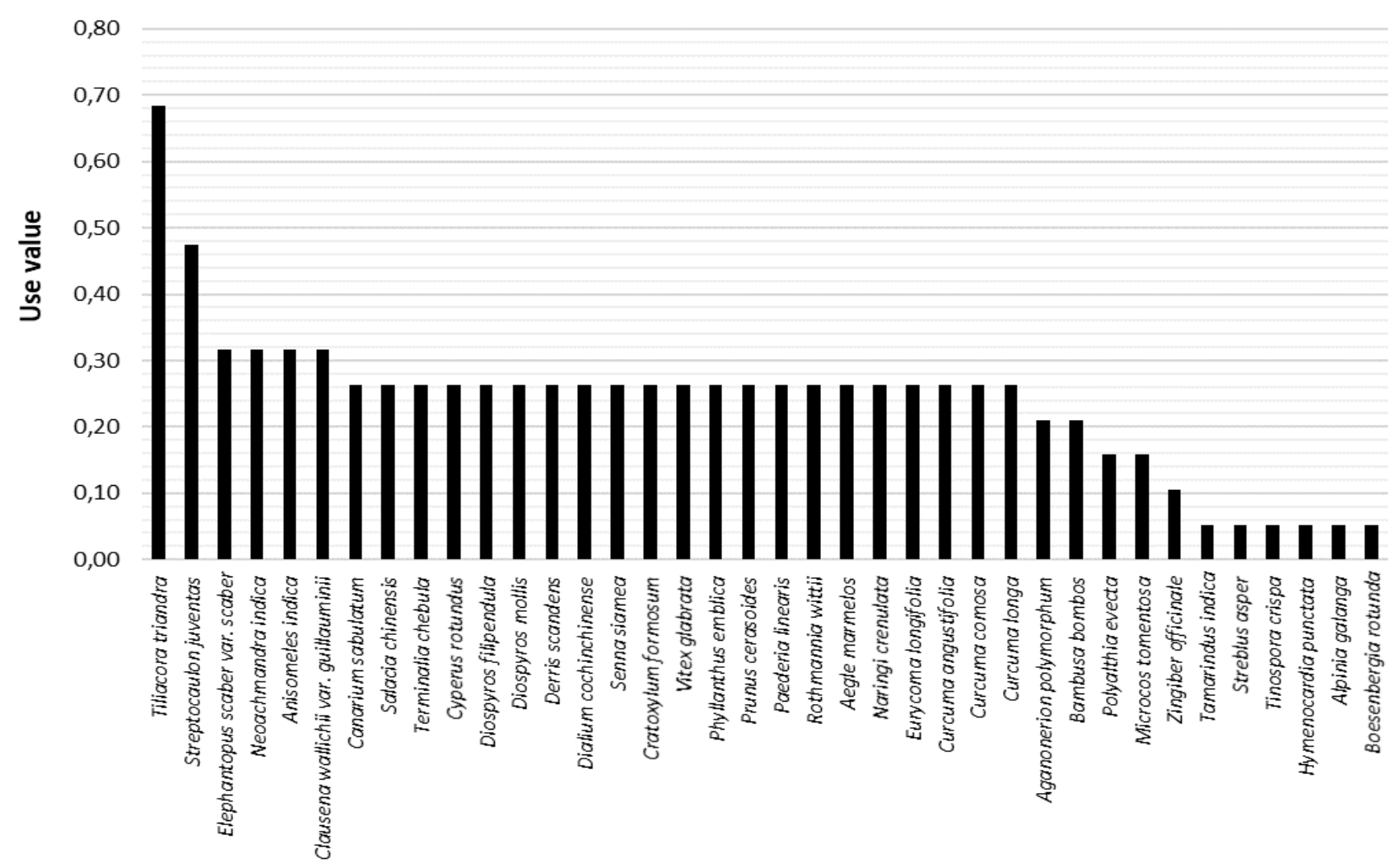

Figure 2. Use values (UV) of medicinal plants in Ban Hua Kua, Kae Dam District, Maha Sarakham Province, Thailand

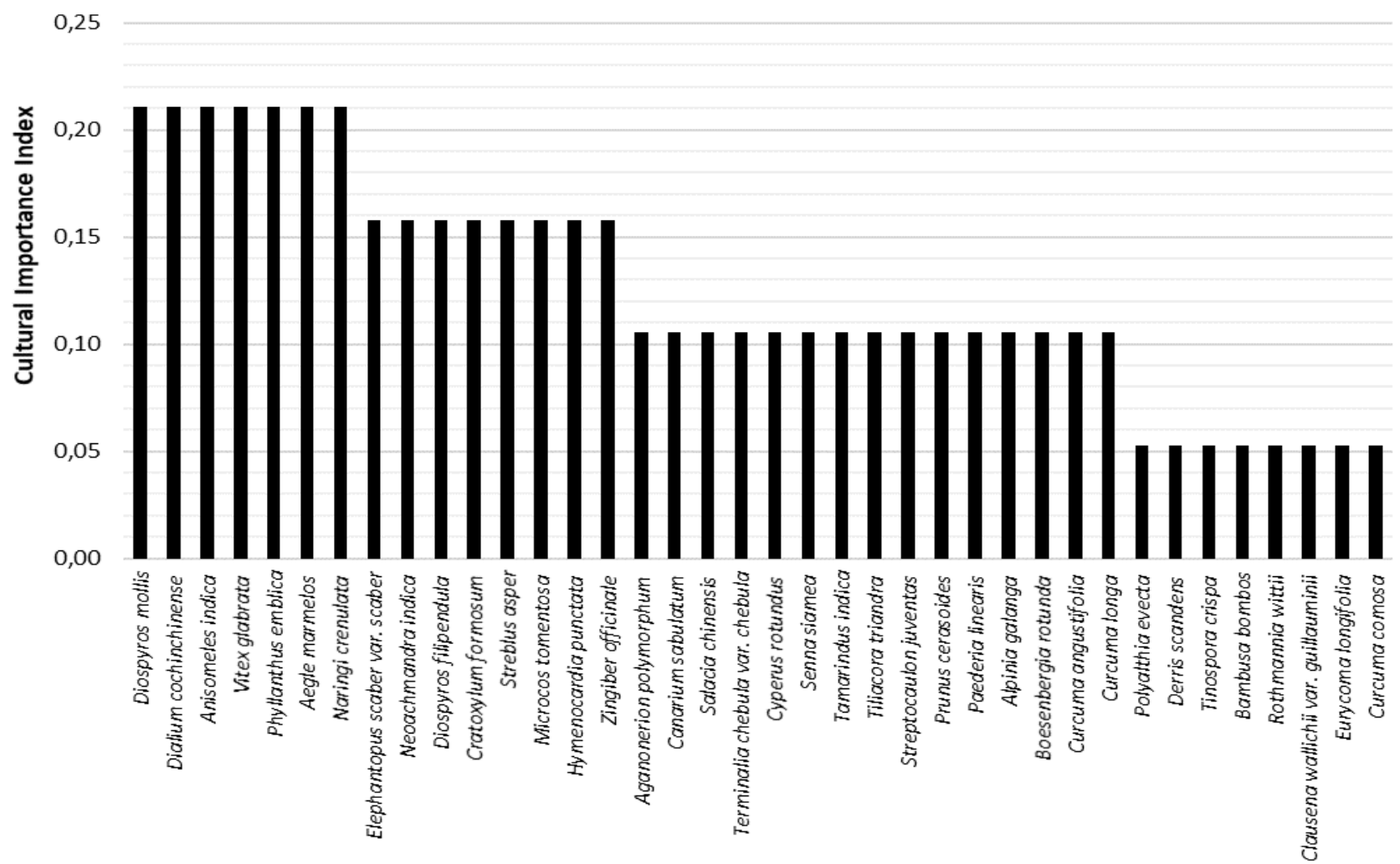

Figure 3. Cultural Importance Index (CI) of medicinal plants in Ban Hua Kua, Kae Dam District, Maha Sarakham Province, Thailand 


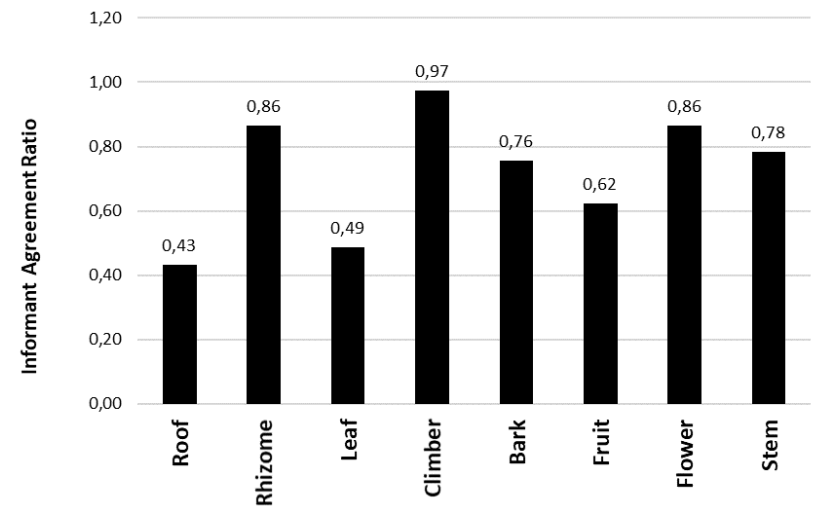

Figure 4. Informant Agreement Ratio (IAR)of medicinal plants in Ban Hua Kua, Kae Dam District, Maha Sarakham Province, Thailand

There are seven species of mostly used plants for utilization, namely Diospyros mollis, Dialium cochinchinense, Anisomeles indica, Vitex glabrata, Phyllanthus emblica, Aegle marmelos, and Hesperethusa crenulata. It is found that Climber is the part of the plant that is mostly used for utilization, followed by rhizome and fruit as the secondranked. Root, leaf, and fruit are also important parts of plants for utilization by local people.

However, more than one part of the plant can be utilized, which is a certain wealth and importance of ethnobotanical information, especially obtained by interviewing the elderly in the community. The medicinal plant in this study might be helpful in other studies likewise developing new medicines or other products. In addition to medicinal plant usage, our study provides insight into the transmission of medicinal plant knowledge. Regardless of time since immigration and gender, we found that younger people have less knowledge of medicinal plants than older ones. This result indicates a loss of accumulated indigenous knowledge, which is likely due to development and modernization that may increase modern medical practices. Further studies are needed to improve the indigenous knowledge of medicinal plants and prevent the loss of indigenous knowledge by documenting medicinal plant identification, treatment preparation, including conservation for sustainable use in the future.

\section{ACKNOWLEDGEMENTS}

This study was financially supported by Walai Rukhavej Botanical Research Institute, Mahasarakham University, and Maha Sarakham Provincial Offices for Natural Resources and Environmentgrant year 2018. We are grateful to the Walai Rukhavej Botanical Research Institute, Mahasarakham University, for allowing us to use their facilities during the fieldwork. In addition, thanks to Dr. Jolyon Dodgson for language editing and suggestions to improve the manuscript.

\section{REFERENCES}

Anderson EF. 1993. Plant and People of the Golden Triangle: Ethnobotany of the Hill Tribe of the Northern Thailand. Whitman College and Desert Botanical Garden, Portland, Oregon.

Albuquerque UP, Lucena RFP. 2004. Seleção e escolha dos informantes. In Métodos e técnicasnapesquisaetnobotânica Edited by: Albuquerque UP, Lucena RFP. Recife: Editora Nupeea.

Bunchalee P, Johnson DM, Murray NA, Chalermglin P. 2021. Three new species of Polyalthia (Annonaceae) from Thailand and Laos. Phytotaxa 512 (4): 272-282. DOI: 10.11646/phytotaxa.512.4.3

Bunwong S, Chantaranothai P, Keeley S. 2014. Revisions and key to the Vernonieae (Compositae) of Thailand. Phytokeys 37: 25-101. DOI: 10.3897/phytokeys.37.6499

Bye RA. 1986. Medicinal plant of Sierra Madre: Comparative study of Tarahumara and Mexican market plants. Econ Bot 40 (1): 103-124. DOI: $10.1007 / \mathrm{BF} 02858951$

Caballero J. 1986. Etnobotánica y desarrollo: búsqueda de buevosrecursos vegetales. In Memorias del IV Congreso Latinoamericano de Botánica, Medellín, ICFES: Simposio de Etnobotánica: Perspectivasen Latinoamérica, Bogotá, Colombia.

Chaudhary MI, He Q, Cheng YY, Xiao PG. 2006. Ethnobotany of medicinal plants from Tian Mu Shan Biosphere Reserve, Zhejiang Province, China. Asian J Plant Sci 5: 646-653. DOI: 10.3923/ajps.2006.646.653

Cook FEM. 1995. Economic Botany Data Collection Standard. Royal Botanic Gardens Kew. United Kingdom.

Middleton DJ. 2009. An update on the Apocynaceae in Thailand. Thai Forest Bulletin (Botany) Special issue: 143-155.

Duangjai S, Sinbumroong A, Suddee S, 2018. Diospyros phengklaii (Ebenaceae), a new species from south-western Thailand. Thai For Bull (Bot) 46 (1): 34-39. DOI: 10.20531/tfb.2018.46.1.05

Gazzaneo LRS, Lucena RFP, Albuquerque UP. 2005. Knowledge and use of medicinal plants by local specialists in a region of Atlantic Forest in the state of Pernambuco (Northeastern Brazil). J Ethnobiol Ethnomed 1 (9): 1-11. DOI: 10.1186/1746-4269-1-9

Hamilton AC, Shengji P, Kessy J, Khan Ashiq A, Lagos-Witte S, Shinwari ZK. 2003. The purposes and teaching of Applied Ethnobotany. People and Plants working paper 11. WWF, Godalming, UK.

Huai HY, Pei SJ. 2004. Plants used medicinally by folk healers of the Lahu people from the Autonomous County of Jinping Miao, Yao, and Dai in southwest China. Econ Bot 58 (1): 265-273. DOI: 10.1663/0013-0001(2004)58[S265:PUMBFH]2.0.CO;2

Inta A, Shengii P, Balslev H, Wangpakapattanawong P, Trisonthi C. 2008. A comparative study on medicinal plants used in Akha's traditional medicine in China and Thailand, cultural coherence or ecological divergence. J Ethnopharmacol 116 (3): 508-517. DOI: 10.1016/j.jep.2007.12.015

Junsongduang A, Kasemwan W, Lumjoomjung S, Sabprachai W, Tanming W, Balslev H. 2020. Ethnomedicinal knowledge of traditional healers in RoiEt, Thailand. Plants 9 (9): 1177. DOI: 10.3390/plants 9091177

Lee S, Xiao C, Pei S. 2008. Ethnobotanical survey of medicinal plants at periodic markets of Honghe Prefecture in Yunnan Province, SW $\begin{array}{lllll}\text { China. J Ethnopharmacol } 117 & \text { (2): 362-377. DOI: }\end{array}$ 10.1016/j.jep.2008.02.001

Martin GJ. 1995. Ethnobotany: A Methods Manual. Chapman \& Hall, London. DOI: 10.1007/978-1-4615-2496-0

Nanakorn W. 1985. The genus Terminalia (Combretaceae) in Thailand. Thai For Bull (Bot) 15: 59-107.

Phengklai C. 1972. The genus Diospyros L. (Ebenaceae) in Thailand. Thai For Bull (Bot) 6: 1-27.

Phillips O, Gentry AH. 1993. The useful plants of Tambopata, Peru: II. Additional hypothesis testing in quantitative ethnobotany. Econ Bot 47 (1): 33-43. DOI: 10.1007/BF02862204

Pholhiamhan R, Saensouk S, Saensouk P. 2018. Ethnobotany of Phu Thai ethnic group in Nakhon Phanom Province, Thailand. Walailak J Sci Technol 15 (10): 679-699. DOI: 10.48048/wjst.2018.3737

Phumthum M, Srithi K, Inta A, Junsongduang A, Tangjitman K, Pongamornkul W, Trisonthi C, Balslev H. 2018. Ethnomedicinal plant diversity in Thailand. J Ethnopharmacol 214: 90-98. DOI: 10.1016/j.jep.2017.12.003

KewScience. 2021. World Checklist of Selected Plant Families (WCSP). 
Pooma R. 1999. A preliminary account of Burseraceae in Thailand. Thai For Bull (Bot) 27: 53-82.

Pooma R. 2002. Further notes on Thai Dipterocarpaceae. Thai For Bull (Bot) 30: 7-27.

Prance GT, Balee W, Boom BM, Carneiro RL. 1987. Quantitative ethnobotany and the case for conservation in Amazonia. Conserv Biol 1 (4): 296-310. DOI: 10.1111/j.1523-1739.1987.tb00050.x

Protection and Promotion of Traditional Medicine Wisdom Act. 1999. Published in the Thai Government Gazette 116: 120.

Saensouk P, Saensouk S. 2021. Diversity, traditional use and conservation status of Zingiberaceae in Udorn Thani Province, Thailand. Biodiversitas 22 (8): 3083-3097. DOI: 10.13057/biodiv/d220801

Saensouk S, Chantaranothai P, Larsen K. 2003. Notes on the genus Alpinia (Zingiberaceae) in Thailand. Thai For Bull (Bot) 31: 95-104.

Saensouk S, Boonma T, Saensouk P. 2021a. Six new species and a new record of Curcuma L. (Zingiberaceae) from Thailand. Biodiversitas 22 (4): 1658-1685. DOI: 10.13057/biodiv/d220410

Saensouk S, Boonma T, Thomudtha A, Thomudtha P, Saensouk P. 2021b. Curcuma wanenluenga (Zingiberaceae), a new species of subgenus Curcuma from Thailand. Biodiversitas 22 (7): 2988-2994. DOI: 10.13057/biodiv/d220752

Saensouk S, Boonma T, Saensouk P. 2021c. A new species and a new record of Curcuma subgen. Curcuma (Zingiberaceae) from Northern Thailand. Biodiversitas 22 (9): 3661-3670. DOI: 10.13057/biodiv/d220903

Sirirugsa P. 1992. A revision of the genus Boesenbergia Kuntze (Zingiberaceae) in Thailand. Nat Hist Bull Siam Soc 40: 67-90.
Srithi K, Balslev H, Wangpakapattanawong P, Srisanga P, Trisonthi, C. 2009. Medicinal plant knowledge and its erosion among the Mien (Yao) in northern Thailand. J Ethnopharmacol 123 (2): 335-342. DOI: $10.1016 /$ j.jep.2009.02.035

Supiadi MI, Mahanal S, Zubaidah S, Julungh H, Ege B. 2019. Ethnobotany of traditional medicinal plants used by Dayak Desa Community in Sintang, West Kalimantan, Indonesia. Biodiversitas 20 (5): 1264-1270. DOI: 10.13057/biodiv/d200516

Susandarina R, Khasanah U, Rosalia N. 2021. Ethnobotanical study of plants used as food and for maternal health care by the Malays communities in Kampar Kiri Hulu, Riau, Indonesia. Biodiversitas 22 (6): 3111-3120. DOI: 10.13057/biodiv/d220613

Sutheewasinnon P, Pasunon P. 2016. Sampling strategies for qualitative research. Parichart J 29 (2): 31-48.

Theilade I. 1999.A synopsis of the genus Zingiber (Zingiberaceae) in Thailand. Nordic J Bot 19 (4): 389-410. DOI: 10.1111/j.17561051.1999.tb01220.x

Thomas E, Vandebroek I, Damme PV. 2007. What works in the field? A comparison of different interviewing methods in ethnobotany with special reference to the use of photographs. Econ Bot 61 (4): 376-84. DOI: 10.1663/0013-0001

Triboun P, Larsen K, Chantaranothai P. 2014. A key to the genus Zingiber (Zingiberaceae) in Thailand with descriptions of 10 new taxa. Thai $\mathrm{J}$ Bot 6 (1): 53-77.

Yineger H, Yewhalaw D, Teketay D. 2008. Ethnomedicinal plant knowledge and practice of the Oromo ethnic group in southwestern Ethiopia. J Ethnobiol Ethnomed 4 (11): 1-10. DOI: 10.1186/17464269-4-11. 